\title{
CXCR4 Inhibitor
}

National Cancer Institute

\section{Source}

National Cancer Institute. CXCR4 Inhibitor. NCI Thesaurus. Code C107589.

An antag onist of the C-X-C chemokine receptor type 4 (CXCR4). CXCR4, which belongs to the G protein-coupled receptor (GPCR) gene family, plays an important role in chemotaxis and ang iogenesis and is upregulated in several tumor cell types. 